Agrika: Jurnal Ilmu-Ilmu Pertanian, Volume 15 Nomor 1, Mei 2021

\title{
PENGARUH PEMBERIAN PUPUK KCL BLACK HORSES TERHADAP PERTUMBUHAN DAN HASIL TANAMAN JAGUNG
}

\section{THE EFFECT OF BLACK HORSES KCL APPLICATION ON THE GROWTH AND YIELD OF MAIZE}

\author{
Fuad Nur Azis ${ }^{1)}$, Lina Aisyawati1), Irma Susanti' ${ }^{1)}$ dan Tri Sudaryono ${ }^{1)}$ \\ ${ }^{1)}$ Balai Pengkajian Teknologi Pertanian Jawa Timur \\ Email: fn_azis@yahoo.com (penulis korespondensi)
}

\begin{abstract}
ABSTRAK
Jagung merupakan salah satu tanaman penting di Indonesia dan memiliki peran strategis dalam perekonomian nasional. Penambahan unsur hara melalui pemupukan merupakan cara untuk meningkatkan hasil. Kalium merupakan senyawa kimia yang sudah dikenal masyarakat untuk pupuk tanaman. Unsur kalium mempengaruhi ketegaran tanaman, merangsang pertumbuhan akar, ketahanan terhadap hama dan penyakit, memperbaiki kualitas biji, dan mampu mengatasi kekurangan air pada tingkat tertentu. Pupuk Black Horses adalah salah satu pupuk anorganik yang mengandung Kalium $\left(\mathrm{K}_{2} \mathrm{O}\right) 60,03 \%$. Tujuan penelitian ini adalah untuk mengetahui pengaruh Pupuk $\mathrm{KCl}$ Black Horses terhadap pertumbuhan dan produksi jagung. Metode penelitian yang digunakan adalah RAK dengan 9 perlakuan dan 3 ulangan. Hasil penelitian menunjukkan bahwa pemberian pupuk $\mathrm{KCl}$ Black Horses efektif secara teknis dan ekonomis meningkatkan produktivitas pada dosis $125 \mathrm{~kg} / \mathrm{ha}(8,42 \mathrm{ton} / \mathrm{ha})$ dan dosis 175 $\mathrm{kg} / \mathrm{ha}(8,89 \mathrm{ton} / \mathrm{ha})$. Seluruh perlakuan secara ekonomis menguntungkan karena memiliki R/C lebih dari 1 . Perlakuan dosis $175 \mathrm{~kg} / \mathrm{ha}$ memberikan R/C tertinggi yaitu 1,87 .
\end{abstract}

Kata Kunci: jagung, pupuk $\mathrm{KCl}$, pertumbuhan, hasil, R/C

\begin{abstract}
Corn is one of the important crops in Indonesia and has a strategic role in the national economy. The addition of nutrients through fertilization is a way to increase yields. Potassium is a chemical compound that is well known as plant fertilizer. The element of potassium affects plant toughness, stimulates root growth, resistance to pests and diseases, improves seed quality, and is able to overcome water shortages at a certain level. Black Horses fertilizer is an inorganic fertilizer containing 60.03\% Potassium (K2O). The purpose of this study was to determine the effect of Black Horses KCl Fertilizer on the growth and production of maize. The research method used was RAK with 9 treatments and 3 replications. The results showed that the application of $\mathrm{KCl}$ Black Horses fertilizer was technically and economically effective in increasing productivity at a dose of $125 \mathrm{~kg} / \mathrm{ha}$ (8.42 tons/ha) and a dose of $175 \mathrm{~kg} / \mathrm{ha}$ (8.89 tons/ha). All treatments were economically advantageous because they had an $R / C$ of more than 1 . The treatment at a dose of $175 \mathrm{~kg} / \mathrm{ha}$ gave the highest $R / C$ of 1.87 .
\end{abstract}

Keywords: maize, $K C l$ fertilizer, growth, yield, $R / C$ 


\section{PENDAHULUAN}

Jagung merupakan salah satu tanaman penting di Indonesia dan memiliki peran strategis dalam perekonomian nasional mengingat fungsinya yang multiguna. Sebagai sumber pangan jagung merupakan sumber karbohidrat kedua setelah beras dan sangat berperan dalam menunjang ketahanan pangan. Selain untuk konsumsi manusia jagung juga memiliki potensi besar untuk kepentingan industri utamanya untuk pakan dan biofuel (Saragih, et al., 2013). Kebutuhan jagung untuk industri pakan ternak sangat tinggi karena jagung merupakan bahan utama pembuatan pakan. Proporsi penggunaan jagung khususnya untuk pakan ayam ras mencapai $51,4 \%$ dari total bahan baku yang digunakan (Tangendjaja et al., 2002). Permintaan jagung untuk industri pakan berkisar 600.000 sampai 750.000 ton per bulan. Laju peningkatan produksi jagung di Indonesia relatif masih lambat, di sisi lain kebutuhan jagung sebagai bahan baku industri pakan dan pangan mengalami peningkatan yang lebih cepat. Kebutuhan jagung yang terus meningkat dari tahun ke tahun, jika tidak diimbangi dengan peningkatan produksi dalam negeri yang memadai akan menyebabkan impor jagung di Indonesia (Moelyohadi, et al., 2012).

Mengingat potensi dan perannya dalam perekonomian nasional, jagung merupakan salah satu komoditas pangan yang mendapatkan perhatian dari pemerintah untuk dikembangkan. Salah satu masalah dalam pengembangan komoditas jagung adalah rendahnya produktifitas di tingkat petani (Zubachtirodin, et al., 2011). Hal ini antara lain disebabkan belum meluasnya penggunaan varietas unggul, belum masifnya penggunaan benih berkualitas di tingkat petani, serta belum optimalnya pengelolaan tanah dan lingkungan seperti pemupukan (Rukmana, 1997; Hamidah, 2009).

Jagung merupakan tanaman yang membutuhkan banyak hara untuk tumbuh dan berkembang (Hidayat, et al., 2015). Penambahan unsur melalui pemupukan optimal merupakan cara untuk meningkatkan hasil sesuai target dan tetap menjaga status kesuburan tanah (Manshuri dan Balai, 2012). Pemupukan optimal berprinsip memberikan pemupukan sesuai dengan 
target hasil tanaman. Pemupukan berlebih mengakibatkan tidak efisiennya penggunaan pupuk. Pemupukan N, P, dan K yang berlebih dalam waktu panjang dapat merusak kesuburan tanah (Shang, et al., 2014).

Kalium merupakan senyawa kimia yang sudah dikenal masyarakat untuk pupuk tanaman. Kalium yang berasal dari abu, kotoran burung, dan kotoran lain. Penelitian mengenai unsur kalium $\left(\mathrm{K}^{+}\right)$sebagai unsur makro esensial telah diteliti. Media tanpa unsur $\mathrm{K}^{+}$menyebabkan tanaman mengalami kematian. Hal ini berbeda dengan unsur makro Nitrogen, Phospor dan Sulfur yang memiliki fungsi utama sebagai unsur pembentuk bahan organik. Kalium memiliki peran sebagai bagan pembangun. Kalium bersifat sebagai aktivator berbagai enzim pada tanaman sehingga proses metabolisme tanaman dapat berlangsung (Suelter, 1985; Page dan Di Cera, 2006).

Unsur kalium mempengaruhi ketegaran tanaman, merangsang pertumbuhan akar, ketahanan terhadap hama dan penyakit, memperbaiki kualitas biji, kematangan yang dipengaruhi oleh Phospor dan mampu mengatasi kekurangan air pada tingkat tertentu. Tanaman yang kekurangan Kalium menunjukkan gejala pertumbuhan kerdil, daun kelihatan kering dan terbakar pada sisi-sisinya, menghambat pembentukan hidrat arang pada biji, permukaan daun memperlihatkan gejala klorotik yang tidak merata dan munculnya bercak coklat mirip gejala penyakit pada bagian yang berwarna hijau gelap (Jin, et al., 2016; Azizzadeh, et al., 2016).

Penelitian ini bertujuan mengetahui pengaruh pupuk terhadap pertumbuhan dan produksi jagung.

\section{METODE}

Penelitian dilaksanakan pada Juli-November 2017. Pelaksanaan penelitian dilakukan di Desa Kemantren, Kecamatan Jabung, Kabupaten Malang. Luas area penelitian ini adalah 0,15 ha.

Bahan yang digunakan adalah jagung varietas Pertiwi 3, Pupuk SP36, Urea, KCl, Pupuk Black Horses, dan pestisida. Pupuk Black Horses mengandung kadar Kalium $\left(\mathrm{K}_{2} \mathrm{O}\right)$ 60,03\% (Tabel 1). Pupuk ini berbentuk kristal berwarna merah. Salah satu 
pupuk $\mathrm{KCl}$ yang banyak beredar adalah pupuk $\mathrm{KCl}$ Mahkota dengan nomor pendaftaran 01.01.2013.075. kandungan pupuk ini sama dengan pupuk KCl Black Horses yaitu 60\% $\mathrm{K}_{2} \mathrm{O}$.

Tabel 1. Analisis pupuk Black Horses

\begin{tabular}{lc}
\hline Parameter & Kandungan Unit \\
& \\
\hline $\mathrm{K}_{2} \mathrm{O}$ & $60,03 \%$ \\
Moisture & $0,43 \%$ \\
Arsenic (As) & $0,27 \mathrm{ppm}$ \\
Mercury $(\mathrm{Hg})$ & $0,01 \mathrm{ppm}$ \\
Cadmium $(\mathrm{Cd})$ & $<0,01 \mathrm{ppm}$ \\
Timbal $(\mathrm{Pb})$ & $<0,01 \mathrm{ppm}$ \\
\hline
\end{tabular}

Penelitian menggunakan Rancangan Acak Kelompok diulang 3 kali dengan jumlah perlakuan sebanyak 9 perlakuan (Tabel 2). Perlakuan kontrol menggunakan dosis tanpa pemupukan seperti panduan yang digunakan dalam Uji Efektivitas Pupuk Anorganik dari Suriadikarta, et al. (2004). Pupuk standar yang digunakan adalah dosis anjuran dari wilayah Kecamatan Jabung Kabupaten Malang berdasarkan anjuran pemupukan spesifik lokasi BPTP Jawa Timur (Arifin, et al., 2016).
Tabel 2. Perlakuan dosis pupuk Black Horses pada tanaman jagung

\begin{tabular}{ccc}
\hline Perlakuan & \multicolumn{2}{c}{ Dosis Pupuk } \\
& $\mathrm{KCl}$ & Black Horses \\
\hline A & 0 & 0 \\
B & 75 & 0 \\
C & 0 & 20 \\
D & 0 & 35 \\
E & 0 & 75 \\
F & 0 & 100 \\
G & 0 & 125 \\
H & 0 & 150 \\
J & 0 & 175 \\
\hline
\end{tabular}

\section{Pengolahan Tanah dan penanaman}

Tanah dibajak dua kali, dirotari dan diratakan. Luas petak perlakuan dibuat dengan plot 3,5x7 m. Petak dibatasi oleh pematang sebesar $25 \mathrm{~cm}$ dan setinggi $25 \mathrm{~cm}$ dan ditandai dengan tali pembatas. Benih jagung ditanam dengan jarak tanam $70 \mathrm{~cm} \times 20 \mathrm{~cm}$. Satu lubang tanam berisi 1 benih jagung.

\section{Pemupukan}

Pupuk dasar berupa upuk organik sebanyak 2 ton/ha bersama dengan dosis SP-36. Pupuk dasar tersebut diberikan bersamaan pengolahan lahan. Pupuk dosis standar di lokasi penelitia adalah 
$350 \mathrm{~kg}$ Urea $100 \mathrm{~kg}$ SP36 dan $75 \mathrm{~kg}$ $\mathrm{KCl}$. Pemupukan organik, urea dan SP36 di setiap petak memiliki dosis yang sama. Dosis dan jenis pupuk $\mathrm{KCl}$ pada setiap petak disesuaikan dengan rancangan penelitian. Tanaman jagung berumur 15 hari setelah tanam dilakukan pemupukan pertama sebanyak 25\% urea dan Pupuk $\mathrm{KCl}$, umur 28 hari $25 \%$ pupuk urea dan Pupuk $\mathrm{KCl}$, dan umur 50 hari pupuk 50\% Pupuk $\mathrm{KCl}$.

\section{Pengendalian organisme pengganggu tanaman (OPT)}

Pengendalian OPT dilakukan dengan penyiangan dan pengendalian hama penyakit tanaman. Penyiangan telah dilakukan pada umur 10, 24, dan 46 hari setelah tanam (HST), Pengendalian hama dan penyakit tanaman dilakukan mulai saat tanam dengan Rodamil dan Furadan. Tanaman yang terserang bulai dikendalikan dengan cara dicabut dan menggunakan pestisida berbahan aktif dimetomorf.

Parameter pengamatan meliputi :

- Tinggi tanaman diukur mulai pangkal batang sampai daun yang tertinggi setelah diluruskan.

- Jumlah daun dihitung daun pada pangkal batang sampai daun paling atas.

- Panjang tongkol $(\mathrm{cm})$ diukur dari pangkal tongkol sampai ujung tongkol setelah kelobot dikelupas, diamati saat panen

- Diameter tongkol $(\mathrm{cm})$ diamati saat panen dari rata-rata pengukuran 3 bagian tongkol yaitu bagian bawah, tengah dan bagian atas tongkol

- Berat 100 biji (g) ditimbang pada kondisi kering dan dikonversi dengan kadar air 14\%. (Mustajab et al., 2015).

- Hasil tongkol per ha basah $(\mathrm{kg})$ dihitung dari hasil konversi berat tongkol per plot tanpa kelobot saat panen.

- Hasil pipilan ( $t / h a)$ dihitung dengan konversi susut berat tongkol menjadi pipil kering pada setiap petak dengan kadar air konversi $14 \%$.

- Biaya pengeluaran setiap komponen usahatani dihitung dari data setiap pembelanjaan bahan dan gaji upah. Data sewa lahan dan penjualan diperoleh dari wawancara petani 
pemilik dan penggarap.

Data yang diperoleh dianalisis menggunakan uji F. Variabel yang berpengaruh nyata diuji lanjut menggunakan BNJ 5\%. Hasil pipilan (ton/ha) tanaman jagung dihitung nilai RAE (Relative Agronomic Effectiveness) (Sudiakarta, 2004). Analisa ekonomi yang dihitung adalah nilai R/C (Asnawi, 2014). Usahatani tani jagung layak dikembangkan secara ekonomis bila R/C lebih dari 1. Pupuk anorganik memiliki kriteria lulus secara teknis apabila secara statistik sama dengan perlakuan standar atau lebih baik dengan kontrol pada taraf nyata $5 \%$. Kriteria lulus secara ekonomis pada pupuk anorganik adalah penilaian analisa usahataninya menguntungkan

(Kementerian Pertanian, 2011).

\section{HASIL DAN PEMBAHASAN}

\section{Karakteristik Lahan}

Penelitian dilakukan pada lahan dengan kondisi agak masam, COrganik dan N-Total rendah. Kandungan $\mathrm{P}_{2} \mathrm{O}_{5}$ dalam tanah tinggi sedangkan $\mathrm{KCl}$ dan $\mathrm{KTK}$ tergolong sedang (Tabel 3). Kondisi tanah ini tepat dilakukan untuk melakukan uji efektivitas kalium karena ketersediaan kalium tidak berlebih dan tidak ada permasalahan dengan faktor kesuburan yang lain.

Tabel 3. Hasil analisis tanah lokasi penelitian

\begin{tabular}{lllll}
\hline No & Parameter Uji & Nilai & Satuan & Klasifikasi* \\
\hline 1 & Kadar air & 7,26 & $\%$ & \\
2 & $\mathrm{pH}$ & & - & \\
& $\mathrm{H} 2 \mathrm{O}$ & 6,2 & - & Agak masam \\
& $\mathrm{KCl}$ & 4,6 & - & \\
3 & $\mathrm{C}$ Organik & 1,16 & $\%$ & Rendah \\
4 & N-Total & 0,12 & $\%$ & Rendah \\
5 & $\mathrm{P}_{2} \mathrm{O}_{5}$ & 29,50 & $\mathrm{ppm}$ & Tinggi \\
6 & Nilai Tukar Kation & & & \\
& Kation dapat ditukar (dd) & 0,43 & me/100g & Sedang \\
& KTK & 23,38 & me/100g & Sedang \\
\hline
\end{tabular}

Keterangan: Klasifikasi berdasarkan Hardjowigeno, 1995 
Hasil sejarah lahan adalah sebagai berikut. Tanaman sebelumnya adalah ubi jalar dan tidak dilakukan pemupukan, sehingga $\mathrm{N}$ dan kandungan bahan organik rendah. Bahan organik penting dalam serapan $\mathrm{P}$ pada tanaman jagung serta dapat mempengaruhi kandungan $\mathrm{N}, \mathrm{P}$, dan $\mathrm{K}$ tanaman (Rachman, et al., 2008). Penambahan bahan organik pemupukan menjadi penting untuk menghindari bias penelitian akibat kekurangan unsur hara terutama $\mathrm{P}$.

Serangan organisme pengganggu tanaman (OPT) yang terdapat di lahan adalah penyakit bulai dan tikus dengan intensitas serangan kurang dari $1 \%$. Gejala bulai muncul di awal pertanaman.

\section{Pertumbuhan Tanaman}

Analisis stastistika menunjukkan bahwa $\mathrm{KCl}$ Black Horses tidak berpengaruh nyata pada pertumbuhan tinggi tanaman dan jumlah daun pada umur 14, 28, 63, 86, dan 92 hari setelah tanam (Tabel 4 dan Tabel 5). Perlakuan A memiliki pertumbuhan tinggi tanaman dan jumlah daun yang sama dengan tanaman jagung yang dipupuk dengan $\mathrm{KCl}$ pada dosis standar maupun dengan $\mathrm{KCl}$ Black Horses.

Tabel 4. Pertumbuhan tinggi tanaman jagung

\begin{tabular}{cccccc}
\hline & \multicolumn{5}{c}{ Tinggi Tanaman $(\mathrm{cm})$} \\
\cline { 2 - 6 } Perlakuan & 14 & 28 HST & 63 HST & 86 & HST \\
& HST & & & HST \\
\hline Uji F & tn & tn & tn & tn & tn \\
A & 31,03 & 39,77 & 170,61 & 189,00 & 232,52 \\
B & 31,62 & 40,37 & 166,08 & 184,01 & 227,13 \\
C & 31,17 & 40,42 & 171,11 & 188,52 & 233,17 \\
D & 31,91 & 40,04 & 163,18 & 179,81 & 229,74 \\
E & 32,54 & 40,87 & 170,87 & 188,26 & 231,50 \\
F & 30,07 & 39,71 & 376,73 & 393,66 & 229,51 \\
G & 32,91 & 39,70 & 174,56 & 191,69 & 220,71 \\
H & 31,42 & 39,99 & 169,73 & 187,19 & 230,51 \\
J & 31,81 & 40,20 & 165,38 & 182,56 & 227,03 \\
\hline
\end{tabular}

Keterangan:

tn : tidak berbeda nyata berdasarkan uji F 5\%

HST : Hari Setelah Tanam 
Tabel 5. Pertumbuhan jumlah daun jagung

\begin{tabular}{cccccc}
\hline & \multicolumn{5}{c}{ Jumlah Daun } \\
\cline { 2 - 6 } Perlakuan & 14 HST & 28 HST & 63 HST & 86 HST & 92 HST \\
\hline Uji F & tn & tn & tn & tn & tn \\
A & 5,78 & 9,56 & 12,33 & 12,33 & 13,00 \\
B & 6,22 & 8,56 & 12,22 & 12,22 & 13,56 \\
C & 6,11 & 8,67 & 12,11 & 12,00 & 13,22 \\
D & 6,00 & 8,56 & 12,00 & 12,11 & 13,33 \\
E & 6,44 & 8,78 & 12,11 & 12,11 & 12,67 \\
F & 6,00 & 9,00 & 12,33 & 12,33 & 13,33 \\
G & 6,00 & 8,67 & 12,33 & 12,33 & 13,00 \\
H & 5,89 & 8,89 & 12,56 & 12,44 & 12,78 \\
J & 6,11 & 8,44 & 12,00 & 12,00 & 12,78 \\
\hline
\end{tabular}

Keterangan:

tn : tidak berbeda nyata berdasarkan uji F 5\%

HST: Hari Setelah Tanam

Kondisi tanah penelitian tidak marginal sehingga kebutuhan kalium sudah terpenuhi untuk pertumbuhan tinggi tanaman. Hal ini terbukti dengan tidak ada perbedaan tinggi tanaman dan jumlah daun setiap waktu pengamatan pada tanaman kontrol dan kalium yang diberikan. Peran $\mathrm{KCl}$ sangat dipengaruhi oleh fase dan kondisi tanah (Jin et al., 2014).

Variabel yang dipengaruhi oleh perlakuan pemupukan adalah panjang tongkol, hasil tongkol basah dan hasil pipilan kering. Diameter tongkol (rerata $5,56 \mathrm{~cm}$ ), berat 100 biji (rerata 30,29 g), dan kadar air (rerata 12,63\%) tidak berbeda nyata berdasarkan Uji F
5\% (Tabel 6 dan Tabel 7). Kadar air pipilan kering juga tidak berbeda nyata.

Kebutuhan kalium pada tanaman berbeda di setiap fase dan organnya. Hal ini karena kalium memiliki peran penting dalam katalis enzim tanaman (Suelter, 1985). Pengaruh terhadap panjang tongkol, hasil tongkol basah dan hasil tongkol pipilan kering dapat terjadi meskipun kalium pada penelitian ini tidak mempengaruhi tinggi tanaman dan jumlah daun. Proses metabolisme pembentukan organ generatif dan vegetatif bebeda. Penelitian ini juga menunjukkan kalium yang diberikan dapat mempengaruhi panjang tongkol walau 
diameter tongkol dan berat 100 biji yang dihasilkan sama.

Tabel 6. Analisis varian komponen hasil dan hasil

\begin{tabular}{lll}
\hline No & Variabel & Uji F \\
\hline 1 & Panjang tongkol & $*$ \\
2 & Diameter tongkol & tn \\
3 & Berat 100 biji & tn \\
4 & Hasil tongkol basah & $*$ \\
5 & Hasil pipilan kering & $*$ \\
6 & Kadar air kering pipilan kering & tn \\
\hline
\end{tabular}

Keterangan:

tn tidak berbeda nyata berdasarkan uji F 5\%

Tabel 7. Diameter dan berat 100 biji

\begin{tabular}{|c|c|c|c|c|c|}
\hline \multirow{2}{*}{ No } & \multicolumn{3}{|c|}{ Dosis pupuk (kg/ha) } & \multirow{2}{*}{$\begin{array}{l}\text { Diameter tongkol } \\
(\mathrm{cm})\end{array}$} & \multirow{2}{*}{ Berat 100 biji ${ }^{\text {tn }}$} \\
\hline & Kode & $\mathrm{KCl}$ & BlackHorses & & \\
\hline 1 & $\mathrm{~A}$ & 0 & 0 & 5,25 & 28,85 \\
\hline 2 & $\mathrm{~B}$ & 75 & 0 & $\begin{array}{c}5,6 \\
7\end{array}$ & 30,03 \\
\hline 3 & $\mathrm{C}$ & 0 & 20 & $\begin{array}{c}5,5 \\
4\end{array}$ & 28,09 \\
\hline 4 & $\mathrm{D}$ & 0 & 35 & $\begin{array}{c}5,3 \\
7\end{array}$ & 30,93 \\
\hline 5 & $\mathrm{E}$ & 0 & 75 & $\begin{array}{c}5,4 \\
9\end{array}$ & 29,59 \\
\hline 6 & $\mathrm{~F}$ & 0 & 100 & $\begin{array}{c}5,6 \\
6\end{array}$ & 31,84 \\
\hline 7 & $\mathrm{G}$ & 0 & 125 & $\begin{array}{c}5,7 \\
0\end{array}$ & 31,26 \\
\hline 8 & $\mathrm{H}$ & 0 & 150 & $\begin{array}{c}5,7 \\
8\end{array}$ & 31,45 \\
\hline 9 & $\mathrm{~J}$ & 0 & 175 & $\begin{array}{c}5,5 \\
4 \\
\end{array}$ & 30,55 \\
\hline
\end{tabular}

Keterangan:

tn:tidak berbeda nyata berdasarkan uji F 5\% 
Pupuk Black Horses dengan yang tercukupi air maupun tanaman dosis 20-175 $\mathrm{kg} / \mathrm{ha}$ memberikan panjang tongkol yang tidak berbeda nyata dengan perlakuan standar. Pupuk Black Horses dengan dosis $35 \mathrm{~kg} / \mathrm{ha}$, $100 \mathrm{~kg} / \mathrm{ha}$ dan $175 \mathrm{~kg} / \mathrm{ha}$ dan pupuk standar $\mathrm{KCl} 75 \mathrm{~kg} / \mathrm{ha}$ meningkatkan panjang tongkol secara nyata dibandingkan dengan perlakuan kontrol (Tabel 8).

Kalium dapat meningkatkan yang kekurangan air meskipun terdapat interaksi dengan varietas dalam pembentukan panjang tongkol (Ahmad et al., 2015). Penelitian ini menunjukkan dosis $35 \mathrm{~kg} / \mathrm{ha}, 100$ $\mathrm{kg} / \mathrm{ha}$ dan $175 \mathrm{~kg} / \mathrm{ha}$ dan pupuk standar $\mathrm{KCl} 75 \mathrm{~kg} / \mathrm{ha}$ dapat mengoptimalkan panajang tongkol yang dihasilkan karena lebih tinggi dibandingkan dengan kontrol.

panjang tongkol pada kondisi tanaman

\section{Panjang tongkol (cm)}

Tabel 8. Panjang Tongkol

\begin{tabular}{|c|c|c|c|c|c|}
\hline \multirow[b]{2}{*}{ No } & \multirow[b]{2}{*}{ Kode } & \multicolumn{2}{|c|}{ Dosis pupuk $(\mathrm{kg} / \mathrm{ha})$} & \multirow{2}{*}{\multicolumn{2}{|c|}{$\begin{array}{l}\text { Panjang } \\
\text { Tongkol }\end{array}$}} \\
\hline & & $\mathrm{KCl}$ & $\begin{array}{l}\text { Black } \\
\text { Horses }\end{array}$ & & \\
\hline 1 & $\mathrm{~A}$ & 0 & 0 & 12,50 & $\mathrm{~b}$ \\
\hline 2 & B & 75 & 0 & 20,00 & $\mathrm{a}$ \\
\hline 3 & $\mathrm{C}$ & 0 & 20 & 18,33 & $a b$ \\
\hline 4 & $\mathrm{D}$ & 0 & 35 & 19,50 & $\mathrm{a}$ \\
\hline 5 & $\mathrm{E}$ & 0 & 75 & 19,17 & $a b$ \\
\hline 6 & $\mathrm{~F}$ & 0 & 100 & 19,83 & $\mathrm{a}$ \\
\hline 7 & $\mathrm{G}$ & 0 & 125 & 18,83 & $a b$ \\
\hline 8 & $\mathrm{H}$ & 0 & 150 & 19,17 & $a b$ \\
\hline 9 & $\mathrm{~J}$ & 0 & 175 & 19,67 & $\mathrm{a}$ \\
\hline
\end{tabular}

Keterangan: Angka yang diikuti huruf yang sama pada kolom yang sama menunjukkan tidak berbeda nyata pada $\mathrm{BNJ} 5 \%$

Pupuk Black Horses dengan dosis $20 \mathrm{~kg} / \mathrm{ha}$ sampai dengan dosis $175 \mathrm{~kg} / \mathrm{ha}$ memberikan hasil tongkol basah yang tidak berbeda nyata dengan perlakuan standar. Pupuk Black Horses dengan dosis $175 \mathrm{~kg} / \mathrm{ha}$ 
dapat meningkatkan panjang tongkol perlakuan kontrol (Tabel 9). secara nyata dibandingkan dengan

Tabel 9. Berat basah tongkol basah jagung (ton/ha)

\begin{tabular}{|c|c|c|c|c|}
\hline \multirow{2}{*}{ No } & \multirow[b]{2}{*}{ Kode } & \multicolumn{2}{|c|}{ Dosis pupuk (kg/ha) } & \multirow{2}{*}{ Hasil tongkol basah (ton/ha) } \\
\hline & & $\mathrm{KCl}$ & Black Horses & \\
\hline 1 & A & 0 & 0 & $11,12 \quad b$ \\
\hline 2 & B & 75 & 0 & $15,28 \mathrm{ab}$ \\
\hline 3 & $\mathrm{C}$ & 0 & 20 & $14,26 \mathrm{ab}$ \\
\hline 4 & $\mathrm{D}$ & 0 & 35 & $15,46 \quad a b$ \\
\hline 5 & $\mathrm{E}$ & 0 & 75 & $13,21 \quad a b$ \\
\hline 6 & $\mathrm{~F}$ & 0 & 100 & $13,92 \mathrm{ab}$ \\
\hline 7 & $\mathrm{G}$ & 0 & 125 & $14,73 \mathrm{ab}$ \\
\hline 8 & $\mathrm{H}$ & 0 & 150 & $14,07 \quad a b$ \\
\hline 9 & $\mathrm{~J}$ & 0 & 175 & $16,01 \quad \mathrm{a}$ \\
\hline
\end{tabular}

Keterangan: Angka yang diikuti huruf yang sama pada satu kolom menunjukkan tidak berbeda nyata pada $\mathrm{BNJ} 5 \%$

Berat tongkol basah merupakan salah satu komponen hasil pada jagung hibrida yang bernilai ekonomi. Petani yang tidak memiliki akses pada tempat penjemuran akan menjual hasil dalam bentuk tongkol basah. Penggunaan kalium dengan dosis $175 \mathrm{~kg} / \mathrm{ha}$ mengakibatkan berat tongkol basah yang lebih besar dari tanaman yang tidak dipupuk. Pemupukan $\mathrm{KCl}$ dosis lain dan dosis standar memberikan

\section{Pipilan kering jagung}

Pupuk Black Horses dengan dosis 20-175 kg/ha $175 \quad \mathrm{~kg} / \mathrm{ha}$ memberikan hasil pipilan kering yang tidak berbeda nyata dengan perlakuan standar. Pupuk Black Horses dengan dosis $125 \mathrm{~kg} / \mathrm{ha}$ dan $175 \mathrm{~kg} / \mathrm{ha}$ meningkatkan hasil pipilan kering secara nyata dibandingkan dengan perlakuan kontrol (Tabel 10).

hasil yang tidak berbeda nyata dengan dosis $175 \mathrm{~kg} / \mathrm{ha}$.

Tabel 10. Berat pipilan kering jagung (ton/ha) 


\begin{tabular}{|c|c|c|c|c|c|}
\hline \multirow{2}{*}{ No } & \multicolumn{3}{|c|}{ Dosis pupuk (kg/ha) } & \multirow{2}{*}{\multicolumn{2}{|c|}{$\begin{array}{l}\text { Hasil pipilan kering } \\
\text { (ton/ha) }\end{array}$}} \\
\hline & Kode & $\mathrm{KCl}$ & Black Horses & & \\
\hline 1 & A & 0 & 0 & 5,94 & $\mathrm{~b}$ \\
\hline 2 & B & 75 & 0 & 7,90 & $a b$ \\
\hline 3 & $\mathrm{C}$ & 0 & 20 & 6,70 & $a b$ \\
\hline 4 & $\mathrm{D}$ & 0 & 35 & 8,28 & $a b$ \\
\hline 5 & $\mathrm{E}$ & 0 & 75 & 6,77 & $a b$ \\
\hline 6 & $\mathrm{~F}$ & 0 & 100 & 7,53 & $a b$ \\
\hline 7 & $\mathrm{G}$ & 0 & 125 & 8,42 & $\mathrm{a}$ \\
\hline 8 & $\mathrm{H}$ & 0 & 150 & 7,63 & $a b$ \\
\hline 9 & $\mathrm{~J}$ & 0 & 175 & 8,89 & $\mathrm{a}$ \\
\hline
\end{tabular}

Keterangan: Angka yang diikuti huruf yang sama pada satu kolom menunjukkan tidak berbeda nyata pada $\mathrm{BNJ} 5 \%$

Berat pipilan kering merupakan variabel hasil utama pada tanaman jagung. Pupuk pada dosis $125 \mathrm{~kg} / \mathrm{ha}$ dan $175 \mathrm{~kg} / \mathrm{ha}$ memberikan hasil pipilan kering yang lebih tinggi dibandingkan kontrol. Dosis $125 \mathrm{~kg} / \mathrm{ha}$ $\mathrm{KCl}$ Black Horses memiliki hasil tongkol basah yang sama dengan kontrol namun hasil pipilan kering memiliki hasil yang lebih tinggi. Hal ini diduga $\mathrm{KCl}$ mampu meningkatkan berat pipilan jagung pada fase pemasakan jagung sehingga kalium yang berada dalam tongkol menuju ke biji. Kalium merupakan mineral yang mobile dalam tanaman (Barker dan Pilbeam, 2015).

\section{Relative Agronomic Effectiveness (RAE)}

Pupuk Black Horses memiliki RAE terendah pada dosis $20 \mathrm{~kg} / \mathrm{ha}$ $(38,78 \%)$ dan tertinggi pada dosis 175 $\mathrm{kg} / \mathrm{ha}(150,51 \%)$. Dosis pupuk Black Horses $35 \mathrm{~kg} / \mathrm{ha}, 125 \mathrm{~kg} / \mathrm{ha}$, dan 175 $\mathrm{kg} / \mathrm{ha}$ memiliki RAE lebih dari $100 \%$, sehingga kedua dosis tersebut merupakan dosis terbaik (Tabel 11). Nilai RAE di atas $100 \%$ menunjukkan bahwa peningkatan hasil agronomis akibat pemupukan lebih tinggi dibanding dengan perlakuan standar atau rekomendasi setempat. 
Tabel 11. RAE pada pupuk Black Horses

\begin{tabular}{ccccc}
\hline & \multicolumn{4}{c}{ Dosis pupuk (kg/ha) } \\
\cline { 2 - 4 } No & Kode & KCl & Black Horses & RAE (\%) \\
\hline 1 & C & 0 & 20 & 38,78 \\
2 & $\mathrm{D}$ & 0 & 35 & 119,39 \\
3 & $\mathrm{E}$ & 0 & 75 & 42,35 \\
4 & $\mathrm{~F}$ & 0 & 100 & 81,12 \\
5 & $\mathrm{G}$ & 0 & 125 & 126,53 \\
6 & $\mathrm{H}$ & 0 & 150 & 86,22 \\
7 & $\mathrm{~J}$ & 0 & 175 & 150,51 \\
\hline
\end{tabular}

3.4. Analisis Usahatani

Biaya, pendapatan dan $\mathrm{R} / \mathrm{C}$ tertinggi terdapat pada perlakuan pupuk Black Horses $175 \mathrm{~kg} / \mathrm{ha}$, sedangkan yang terendah pada kontrol. Seluruh perlakuan memiliki $\mathrm{R} / \mathrm{C}$ lebih dari satu hal tersebut menunjukkan secara finansial seluruh perlakuan menguntungkan (Asnawi, 2014), yang berkisar dari Rp. 4.635.000-Rp. 13.209.250.

Budidaya jagung nasional memiliki rerata $\mathrm{R} / \mathrm{C}$ 1,73 dengan keuntungan 6,7 juta rupiah per hektar (Suryana dan Agustian, 2014). Hal tersebut menunjukkan bahwa perlakuan pemupukan dosis standar, $\mathrm{KCl}$ Black Horses dosis 35, 125, dan $175 \mathrm{~kg} / \mathrm{ha}$ memiliki $\mathrm{R} / \mathrm{C}$ diatas rerata nasional.

\section{KESIMPULAN}

Pupuk KCl Black Horses pada dosis tertentu efektif secara teknis dan ekonomis dalam meningkatkan hasil jagung. Secara teknis budidaya, pupuk $\mathrm{KCl}$ Black Horses dengan dosis 125 dan 175 $\mathrm{kg} / \mathrm{ha}$ efektif meningkatkan produksi jagung, yaitu berturutturut sebesar 8,42 ton/ha dan dosis 8,89 ton/ha. Secara ekonomis pupuk $\mathrm{KCl}$ Black Horses dengan dosis $175 \mathrm{~kg} / \mathrm{ha}$ memiliki R/C tertinggi yaitu 1,87 .

\section{DAFTAR PUSTAKA}

Ahmad, N., Khan, M.B., Farooq, S., Shahzad, M. dan Hussain, M. 2015. Potassium Nutrition for Improving the Maize Performance under Water Deficit Conditions. Soil Environment. 34(1): 15-20. 
Asnawi, R. 2014. Peningkatan produktivitas dan pendapatan petani melalui penerapan model pengelolaan tanaman terpadu padi sawah di Kabupaten Pesawaran , Lampung. Jurnal Penelitian Pertanian Terapan. 14(1): 4452.

Azizzadeh, E., Naeini, S.A.R.M., Zeinali, E. dan Roshani, G.A. 2016. Nitrogen, phosphor and potassium changes in soil and wheat under foliar application of Leonardite, $\mathrm{N}$ and $\mathrm{K}$. International Journal of Advance Biological and Biomedical Research. 4(2): 193-201.

Barker, A. V. dan Pilbeam, D.J. 2015. Handbook of plant nutrition. CRC Press.

Hamidah, E. 2009. Pengaruh dosis pupuk urea dan macam varietas terhadap pertumbuhan dan produksi jagung (Zea mays L.). Saintis. 1(2): 105114.

Hardjowigeno, S. 1995. Genesis dan Klasifikasi Tanah. IPB. Bogor.

Hidayat, A.M., Ambarwati, E., Wedhastri, S. dan Basunanda, P. 2015. Pengujian lima pupuk organik cair komersial dan pupuk NPK pada jagung ( Zea mays L .). Jurnal Vegetalika. 4(4): 9-20.

Jin, J., Liu, X. dan He, P. 2014. Does potassium or chloride play a dominant role in suppression of corn stalk rot? Effectiveness of Potash Fertilization. hal.7-9.
Jin, J., Liu, X. dan He, P. 2016. Does potassium or chloride play a dominant role in suppression of corn stalk rot? Effectiveness of Potash Fertilization. Georgia: IPNI, hal.7-9.

Kementerian Pertanian 2011. Peraturan Menteri Pertanian Nomor 43/Permentan/SR.140/8/2011 tentang Syarat dan Tata Cara Pendaftaran Pupuk AnOrganik. Jakarta: Kementerian Pertanian.

Manshuri, A.G. dan Balai 2012. Optimasi pemupukan NPK pada kedelai untuk mempertahankan kesuburan tanah dan hasil tinggi di lahan sawah. Iptek Tanaman Pangan. 7(1): 38-46.

Moelyohadi, Y., Harun, M.U., Hayati, R. dan Gofar, N. 2012. Pemanfaatan berbagai jenis pupuk hayati pada budidaya tanaman jagung (Zea mays L.) efisien hara di lahan kering marginal. Jurnal Lahan Suboptimal. 1(1): 31-39.

Mustajab, Sembodo, D.R.J. dan Hamim, H. 2015. Efikasi Herbisida Atrazin terhadap Gulma Umum pada Lahan Budidaya Tanaman Jagung (Zea mays L.). Jurnal Penelitian Pertanian Terapan. 15(1): 8-14.

Page, M.J. dan Di Cera, E. 2006. Role of $\mathrm{Na}^{+}$and $\mathrm{K}^{+}$in Enzyme Function. Physiological Reviews. 86(4): 1049-1092. http://physrev.physiology.org/ cgi/doi/10.1152/physrev.0000 8.2006 . 
Rachman, I.A., Djuniwati, S. dan Idris, K. 2008. Pengaruh bahan organik dan pupuk NPK terhadap serapan hara dan produksi jagung di inseptisol Ternate. Jurnal Tanah dan Lingkungan. 10(1): 7-13.

Rukmana 1997. Usaha Tani Jagung. Yogyakarta: Kanisius.

Saragih, D., Hamim, H. dan Nurmauli, N. 2013. Pengaruh dosis dan waktu aplikasi pupuk urea dalam meningkatkan pertumbuhan dan hasil jagung (Zea mays L.) Pioneer 27. J Agrotek Tropika. 1(1): 50-54.

Shang, Q., Ling, N., Feng, X., Yang, X., Wu, P., Zou, J., Shen, Q. dan Guo, S. 2014. Soil fertility and its significance to crop productivity and sustainability in typical agroecosystem: A summary of long-term fertilizer experiments in China. Plant and Soil. 381(12): 13-23.

Suelter, C.H. 1985. Role of Potassium in Enzyme Catalysis. Potassium in Agriculture. hal.337-349.

Suryana, A. dan Agustian, A. 2014. Analisis daya saing usahatani jagung di Indonesia. Analisis Kebijakan Pertanian. 12(2): 143-156.

Tangendjaja, B., Yusdja, Y. dan Ilham, N. 2002. Analisis ekonomi permintaan jagung untuk pakan. Ekonomi Jagung Indonesia. Jakarta: Badan Penelitian dan Pengembangan Pertanian, hal.229-254.
Zubachtirodin, S, S. dan Mulyono., H.D. 2011. Teknologi Budidaya Jagung. Jakarta: Direktorat Jenderal Tanaman Pangan, Kementerian Pertanian. 